\title{
THE SYSTEM OF RICE INTENSIFICATION (SRI) AS A SYSTEM OF AGRICULTURAL INNOVATION
}

\author{
Norman Uphoff \\ Cornell International Institute for Food, Agriculture and Development (CIIFAD), \\ Cornell University, Itacha, New York USA
}

\begin{abstract}
The System of Rice Intensification (SRI), developed in Madagascar some 25 years ago, is gaining increasing credence and momentum as probably 500,000 farmers in more than 20 countries are now using its methods to raise their rice production -- while also reducing their use of external inputs and production costs. Rather than focus on the innovation itself, this paper will introduce SRI only briefly, focusing instead on the transnational system for innovation that has emerged in response to this agronomic opportunity that can be particularly beneficial for resource-limited households. Within SRI's conceptual and practical framework, farmers have devised many innovations. These are the focus of a parallel paper written for this workshop. That paper considers how farmers have made the original SRI methodology less labor-intensive (even labor-saving), and how they have extended methods devised for irrigated rice production both to unirrigated (rainfed) areas for growing rice and to other crops beyond rice. This paper is concerned with what can be considered as a de facto 'system of innovation' that surrounds and has accelerated the spread of SRI worldwide. SRI has differed from most other agricultural innovations in the extent to which farmers have voluntarily invested their own time and resources in taking SRI to peers as an impressive example of farmer-to-farmer extension. Also, innovative alliances have formed among diverse persons and organizations to disseminate and adjust the methodology, thereby supporting the spread of this innovation even despite resistance from some established institutions.
\end{abstract}

\section{A CIVIL-SOCIETY INNOVATION}

The System of Rice Intensification (SRI) is an unusual innovation in several ways in that its methods can raise, concurrently, the productivity of the land, labor, water, and capital invested in irrigated rice production. This positivesum dynamic violates precept that 'there are no free lunches,' which assumes that there must always be some tradeoff. Of course, there are costs involved with SRI adoption, particularly increased labor from farmers during their initial learning phase; and there are some conditions where the methods will be inappropriate or impractical, e.g., where there is little water control and flooding creates anaerobic soil conditions. But with skill and confidence as well as innovation, SRI can become labor-saving over time, saving water (by $25-50 \%$ ) and seed (by $80-90 \%$ ), reducing costs (by $10-20 \%$ ), and raising paddy output at least 25 $50 \%$,and often $50-100 \%$ and sometimes even more. This sounds too good to be true, of course; but the productivity of SRI methods has been validated in 28 countries, from China to Cuba, Peru to Philippines, Gambia to Zambia, and even in Iraq, Iran and Afghanistan. See SRI website: http://ciifad.cornell.edu/sri/ for information on these and other country experiences.

SRI works by changing the management of the plants, soil, water and nutrients utilized in paddy rice production. Specifically, it involves transplanting single young seedlings with wider spacing, carefully and quickly into fields that are not kept continuously flooded, and whose soil has more organic matter and is actively aerated, as described below. These practices improve the growth and functioning of rice plants' root systems and enhance the numbers and diversity of the soil biota that contribute to plant health and productivity (Stoop et al., 2002; Uphoff, 2003; Randriamiharisoa et al., 2006; Mishra et al., 2006).

The cumulative effect of these methods is raise not only the yield of paddy ( $\mathrm{kg}$ of unmilled rice harvested per hectare) without relying on improved varieties or agrochemical inputs, but also to increase the outtum of milled rice, i.e., $\mathrm{kg}$ of consumable rice per bushel of paddy, by $10-15 \%$. This 'bonus' on top of higher paddy yields is due to having fewer unfilled grains (less chaff) and fewer broken grains (less shattering).

In addition, farmers report - and researchers have verified - that SRI crops are more resistant to most pests and diseases, and better able to tolerate adverse climatic influences such as drought, storms, hot spells or cold snaps. The length of the crop cycle (time to maturity) is also reduced, with higher yields. Resistance to biotic and abiotic stresses will become more important in the coming decades as farmers around the world have to cope with the effects of climate change and the growing frequency of 'extreme events.' The resistance of SRI rice plants to lodging caused by wind and/or rain, given their larger root systems and stronger stalks, can be quite dramatic, as seen from the picture below. In general, one can say that use of SRI methods reduces the agronomic and economic risks that farmers face (Uphoff, 2007). 


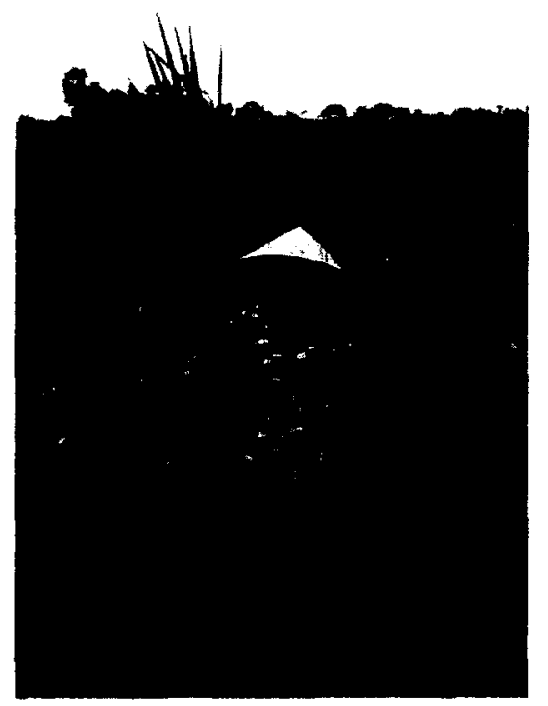

Figure 1. A farmer-field-school graduate in Vietnam holding up a single SRI plant on the left and a 'regular' rice plant on the right after a typhoon had passed over in front of the respective paddy fields in which the plants were grown. (Picture courtesy of Elske van de Fliert)

SRI differs from most agricultural technologies promoted in recent decades in that it is a civil-society innovation, originating not from research stations or laboratories, but from the dedicated work of a Jesuit priest, subsequently amplified and adapted through the efforts of farmers, NGOs and other non-state actors. Father Henri de Laulanié spent 34 years of his life, the last 34, working with small-scale farmers in Madagascar to devise better ways to raise paddy yields with the aim of reducing the pervasive poverty and hunger in that country (Laulanié, 2003). He sought low-cost methods that did not rely on expensive and environmentally-unfriendly external inputs and was able to succeed in his objective just by modifying the way that rice plants, soil, water and nutrients are managed (Laulanié, 1993).

Roughly since World War II, agricultural innovations have usually followed a linear sequence in which advances in scientific knowledge are made and then transformed into technological advances. These are then disseminated through extension (government) or market (private sector) mechanisms to users, called adopters. SRI as an innovation follows an earlier pattern where, conversely, technology preceded science, similar to the sequence seen in the emergence of air travel and transport. The Wright brothers, who made the first heavier-than-air vehicle, were bicycle mechanics with an aspiration for flight that they accomplished through tinkering and sheer empiricism, without benefit of any science of aerodynamics.
This came later, explaining and improving upon the brothers' materialization of their idea. New knowledge for flight followed from invention, rather than scientific knowledge itself leading the process of innovation.

The spread and improvement of Fr. de Laulanie's innovation -- the result of decades of observation and experimentation (Uphoff, 2005) -- was initially undertaken by an NGO that he established in 1990 with some of his Malagasy colleagues, Association Tefy Saina. Their effort was expanded subsequently through collaboration with a North American university, working with the Cornell International Institute for Food, Agriculture and Development (CIIFAD) which has worldwide networking connections. For the most part, the innovation was received by the scientific community with indifference or sometimes hostility, judging from published assessments of SRI (Doberman, 2004; McDonald et al., 2006; Sheehy et al., 2004; Sinclair, 2004; Sinclair and Cassman, 2004; see Surridge, 2004).

Some scientists responded to the SRI challenge/ opportunity affirmatively, however, first in Madagascar, then in China, Indonesia, India, Gambia, Japan and other countries. Those who took SRI seriously rather than dismissing it without personal acquaintance were scientists who were open to working with farmers and NGOs, not regarding work on research stations or in laboratories as sufficient. 
They were willing to visit SRI fields and to talk with SRI farmers, less disposed to rely on a priori reasoning and secondary data, not reflexively inclined to 'defend' their scientific enterprise against the 'intrusions' of nonscientists who were suggesting reasons for a paradigm shift in rice production. Most of the early work on SRI was taken up by NGOs, farmers, and individuals with curiosity about how it could be possible to 'get more from less,' appreciating that this would greatly benefit farmers, consumers, and the environment if the claims of SRI could indeed be validated.

Persons who think that farmers' knowledge deserves invariant respect and deference may be surprised by the SRI story, however. Laulanié's empirical work (Uphoff, 2005) showed that most of the practices that rice farmers had followed for generations -- using older rather than younger seedlings, spacing these closely rather than sparsely, and growing them in flooded rather than welldrained fields - are, in fact, sub-optimal. That conventional agronomic practices constrain yield expression can be shown now with solid scientific evidence and reasoning. To be sure, Laulanié learned several of the most beneficial SRI practices from observing the 'deviant' practices of some Malagasy farmers - transplanting seedlings singly instead of in clumps of many plants, and not keeping paddy fields always inundated. But some of the key practices that rice farmers have used for centuries, even millennia, constrain rice productivity. One should not assume, therefore, that through years of trials and error farmers have always worked out the best of all possible practices. In the case of irrigated rice, this is demonstrably not true.

Farmers have not been alone in believing firmly in methods that are demonstrably sub-optimal, however. Some leading rice scientists have strongly endorsed practices that can be shown to be yield-limiting, e.g., asserting that rice plants perform better when submerged in standing water (DeDatta, 1981). For many years, both farmers and scientists have observed from fields that were not perfectly leveled that rice plants growing in low-lying areas, always flooded, struggled and grew poorly -compared to those plants growing in higher, better-drained areas, which prospered. Neither farmers nor scientists drew the appropriate conclusion from their observations that rice is not really an aquatic plant, appreciating that rice grows better in soil that is kept moist but well-drained, even intermittently dried out to some extent.

Keeping paddy soils mostly aerobic, as accomplished with SRI methods, favors better root growth and health while also contributing to more abundant and diverse populations of (mostly aerobic) soil biota. These organisms produce many benefits for a rice crop (Randriamiharisoa $e t$ al., 2006).

However, the belief that rice grows better under flooded conditions still persists among most farmers and many rice scientists despite research disproving this, e.g., Ramasamy et al. (1997); Guerra et al. (1999).
Actually, farmers have flooded their paddy fields mostly to reduce the amount of labor required for controlling weeds -- not comprehending how big a yield penalty they pay for suffocating the roots of their rice plants and reducing the populations of aerobic organisms that (should) live in the soil for it to be most fertile.

Moreover, for many years agronomists have warned against what they call the 'border effect' or 'edge effect.' Whenever crop-cut samples are taken to estimate the yield of a field, we are told that samples should be taken from randomly-selected areas in the middle of the field, not from along the edge of the field. Why? Because it is known that plants growing on the borders of fields, being more exposed to sunlight and air circulation, are healthier and give more yield (Gomez and DeDatta, 1971). 'By introducing optimally wider spacing, however, SRI methods achieve 'the border effect' for the whole field. If there is a significant difference between the productivity of border plants vs. center plants, bias in measurement should be avoided. But a 'border effect' is something that farmers should try to achieve, rather than avoid.

These are just two of the ways in which rice farmers as well as scientists have been wrong about what constitute the most productive practices. Past beliefs and techniques have suppressed rice yield potential. As developed by Laulanié and further evolved by farmers, NGOs and researchers around the world over the past decade, SRI is capitalizing on this potential, getting more productive phenotypes from practically all rice genotypes, traditional or modern, local or improved, indigenous or high-yielding.

These insights have come more from observation and experimentation than from scientifically-formulated hypotheses and controlled trials. As a civil society innovation, the main criterion for evaluation of SRI has been farmer satisfaction and demonstrable economic and environmental benefits, rather than peer review and publications in the scientific literature. Both the innovation and the ways in which it has been validated and disseminated are unusual, possibly pointing out directions for other agricultural advances.

\section{SRI AS A SYSTEM FOR AGRICULTURAL INNOVATION}

SRI is remarkable not only in its origins and in the benefits that it can create, but also in the ways that it is being developed and extended, as individuals and civil society organizations have taken responsibility for SRI promotion in ways not common in the agricultural sector. While there is now considerable literature, such as cited above, that discusses the innovation itself, pro and con, the system for innovation that has emerged through and around SRI has received relatively little attention and analysis so far. $^{2}$

\footnotetext{
'Sato and Takahashi (1983) reported, for example, that rice plants in burder rows can give $45-249 \%$ more yield than those in the center of a field; and external rows of wheat and bariey have been reported to produce $40 \%$ more grain than was harvested from the innermost rows (Romani et al., 1993).

${ }^{2}$ Except from Shambu Prasad (2006) and Shambu Prasad et al. (2007) regarding the spread of SRI in India. Shambu Prasad discussed this research on Day 2 of the workshop.
} 
Concepts from the realm of computers and data processing may help to present experience with SRI. The initial concepts of central direction and control that are represented by a central processing unit have not applied. SRI has proceeded with massive parallel processing, and indeed with indeed problem solving that is widely distributed. The two-track strategy discussed below is based on such an approach. SRI has been explicitly conceived of and presented not as a technology but rather as a methodology based on a set of ideas and insights formulated as principles that are to be translated into specific practices, which seek to create a more favorable growing environment for irrigated rice plants.

Proponents stress that SRI is not finished yet. It is a work in progress, still evolving and improving. It is continuously being adapted for diverse environments as these environments and SRI become better understood. There is an interesting parallel with high-yielding varieties (HYVs), which started with IR-8, a fairly versatile and adaptable genotype. IR-8 was succeeded by many newer HYVs developed to be more productive in specific environments or to deal with particular constraints (pest, disease, soil nutrition, etc.). SRI keeps diversifying as more people become involved with it and as experience is gained. This makes it more appropriate for everyone to use the term 'SRI' as an adjective rather than as a noun.

SRI is an innovation that encourages further innovation, not being a material set of inputs or a packaged set of instructions to be implemented like the Green Revolution technology. It can best be summarized as a set of ideas or insights, rather than fixed prescriptions. ${ }^{3}$ The actual practice of SRI has been dynamic while at the same time the core ideas of SRI that emerged from Laulanie's work have remained quite stable and robust over the eight years since they were first taken outside Madagascar. ${ }^{4}$ They have, however, been extended and adapted both to unirrigated rice production and to other crops.
A parallel paper written for this workshop reports on innovations that farmers have introduced in SRI, going beyond the original SRI concepts and practices. This they have done usually on their own, but often in cooperation with NGO or government personnel who are working with farmers in a collaborative mode. Knowing what innovations have emerged makes more palpable the system of innovation that has arisen.

\section{STRATEGIES FOR DISSEMINATION}

Because SRI is such an unusual innovation, it should not be surprising that the ways in which it has been disseminated are themselves not typical. SRI was not planned as a civil-society innovation; it has just evolved that way. Laulanié and Tefy Saina would gladly have had the government in Madagascar join in spreading knowledge of SRI, but there was resistance to the new ideas from agricultural researchers (FOFIFA) as with few exceptions, government personnel were hostile. Sadly, this has been true, at least initially, in practically all other countries where the ideas have been introduced. Thus, SRI has spread, by force of circumstance, through the efforts of a great variety of individuals with NGO, university, farmer organization or other affiliations who shared an interest in low-external-input, sustainable or 'alternative' agriculture.

The Cornell International Institute for Food, Agriculture and Development (CIIFAD), established in 1990 at Cornell University with a generous and anonymous private gift to work collaboratively for sustainable agricultural and rural development in lessdeveloped countries, learned about SRI from Association Tefy Saina in Madagascar in 1993.

Together, CIIFAD and Tefy Saina in 1993-1994 began jointly evaluating and promoting SRI use in the peripheral zone around Ranomafana National Park under a USAID-funded project.

\footnotetext{
'The basic concepts of SRI can be summarized succinctly as follows:

1. Use young seedlings to preserve mature plants' growth potential -- although direct seeding is becoming an option with SRI, a major change in the original concept, thanks to farmer innovation.

2. Avoid trauma to the roots - transplant quickly, shallow $(1-2 \mathrm{~cm})$, with no inversion of seedlings' root tips that will delay the plants' resumption of growth after transplanting.

3. Give plants optimally wider spacing - one plant per hill and in square pattern so as to achieve 'the border effect' for the whole field.

4. Keep paddy soil sufficiently moist but not continuously flooded mostly aerobic and not saturated. This concept has been adapted for rice-growing in rainfed, unirrigated areas, with considerable success.

5. Actively aerate the soil as much as possible, using a rotary hoe or conoweeder to control weeds.

6. Enhance soil organic matter as much as possible applying compost, mulch, manure. etc. Chemical fertilizers can be used with SRI, but the best results have come with organic soil amendments.
}

The first three practices stimulate plant growth, while the latter three practices purposefully enhance the growth and health of plant roots and soil biota. Other beneficial practices get recommended for use with SRI, such as selection of most suitable varieties, doing good seed selection, possibly doing also seed priming and seedbed solarization (Culman et al., 2005), or using raised beds. But these are not practices that stem from the work and insights of Laulanic, so we prefer not to conflate them with SRI. He would have been adamant in advocating and endorsing continuous modification and evolution of SRI, approving of anything that will benefit rural households and the environment.

\footnotetext{
4 First at Nanjing Agricultural University in China in 1999; then at the Sukamundi rice research station of the Agency for Agricultural Research and Development in Indonesia in 1999-2000. Also in 1999-2000, SRI was introduced in Bangladesh by pioneering district staff of an NGO. CARE/Bamgladesh, and the Dept. of Agricultural Extension. This shows the diverse kinds of institutions involved with SRI from outset.
} 
After seeing farmers who had previously gotten paddy yields of only 2 tha achieve achieve average yields of $8 \mathrm{t}$ tha for three consecutive years -- without adopting new varieties or depending on chemical fertilizer -. as the director of CIIFAD I began trying to get these methods evaluated outside of Madagascar. No institutions in Madagascar apart from a few NGOs showed any interest in SRI, and the IRRI representatives based in Madagascar explicitly rejected SRI and made no effort to evaluate and understand it (pers. comm.). At my own university, Cornell, I was not able to evoke much interest.

The first interest in SRI expressed outside Madagascar came from the International Institute for Rural Reconstruction (IIRR), an NGO in the Philippines, which invited Tefy Saina's secretary to talk about SRI at an NGO conference on rice that it convened in June 1998, cosponsored by ILEIA based in the Netherlands. From this came a short article published on SRI (Rabenandrasana, 1999).

About the same time, a longer article on SRI was published, written in more standard academic style, based on a paper presented to a Bellagio conference on sustainable agriculture (Uphoff, 1999). Over the next few years, ILEIA published several more articles on SRI, and another NGO dedicated to smallholder agricultural improvement, ECHO, based in Ft. Myers, Florida, published an article that gave SRI further impetus (Berkelaar, 2001).

There is not enough space here to give details on the spread of SRI through word of mouth, photocopies, unpublished reports, e-mail contacts, etc. In footnote 3 , it was mentioned that the first uptake of SRI was by individuals in diverse institutions: a university, a government research agency, an NGO, and an extension service, in countries ranging across East, Southeast and South Asia. The variety of persons who emerged as initiators of SRI evaluation and promotion is itself remarkable: an animal nutritionist in Cuba, agronomists working with NGOs in Cambodia and Myanmar, a senior civil servant in Sri Lanka, an electrical engineer in Philippines, a university researcher in India, a retired professor in Bangladesh, a government researcher from Gambia (doing graduate studies at Cornell). China was the only country where the agricultural research establishment quickly showed much openness to SRI (Yuan, 2001, 2002; see also Chinese reports in Uphoff et al., 2002).

Through e-mail communication and eventually an SRI website on the internet (http://ciifad.comell.edu/sri) CIIFAD began facilitating exchanges of experience, information and ideas from 2000 on. By 2002, with support from an innovative program officer in the Rockefeller Foundation, it was possible to organize an international conference to assess SRI. This was hosted by the China National Hybrid Rice Research and Development Center and by its director, Prof. Yuan Longping, world-famous as 'the father of hybrid rice.'
Association Tefy Saina. Because its evaluation of Sri had validated the benefits of SRI to its satisfaction, the China National Rice Research Institute in Hangzhou also became a co-sponsor. The conference brought together 50 international participants and even more Chinese researchers and officials for four days of presentations and discussions. The proceedings (http://ciifad.cornell.edu/sri/procl/index.html) created a repository of SRI information that served the dissemination of SRI very well. The various papers, widely available via the internet, combined research, extension, NGO, policy-maker and farmer perspectives in a rather unusual way.

The outlines of an SRI innovation system were set by this event which had positive reverberations for years to come. The mix of people who became involved in SRI continued to include the range mentioned above. At Sanya there was agreement on a 'two-track strategy' in which, concurrently, researchers would try to advance the scientific understanding of SRI while extension and NGO personnel working with farmers would attend to the practical adaptation and promotion of the methods. Each 'track' was expected to interact with -- and to contribute to -. the other. This 'parallel processing' has been a hallmark of SRI. Since SRI involved no genetic modification and no chemical inputs, no loans or capital requirements, only some element of risk and some initial discomfort of neighbors' skepticism and even derision, there was little cost or harm in trying it, perhaps on only a small area. If the new methods were not more productive, farmers could easily revert to their earlier practices. But $>90 \%$ of the time, obvious gains were achieved.

Meanwhile, although the IRRI programs in Laos and Bangladesh assisted systematic evaluation of SRI, there began appearing a series of articles from scientists at or allied with IRRI (and one from Cornell) that dismissed SRI. Most of these skeptics/critics had never themselves worked with SRI in the field or made an effort to leam from farmers who had experience with SRI (Dobermann, 2004; McDonald et al., 2006; Sheehy et al., 2004; Sinchir and Cassman, 2004; Sinclair, 2004). 'This did not inhibit their reaching and publishing negative conclusions.

That SRI is 'not a technology' and does not rely on saleable inputs has made it difficult for most existing extension organizations to comprehend and promote the innovation. (The Tripura extension service in India is an exception:

http://ciifad.cornell.edu/sri/countries/india/inntutrep 1007.p df). It has been observed that current extension systems are usually better at distributing goods or services than at communicating ideas (Ravindran, 2007).

\footnotetext{
'An exception was Moser and Barrett (2003), which was empirically based and found considerable 'disadoption' of SRI in the five villages studied. These, however, were not representative of the overall
} 
Extension personnel seem happiest or most comfortable when giving out seeds or fertilizer or implements, not patiently explaining to and coaching farmers. There is also a problem of incentives with Sri in that it provides no material benefits that can be pocketed by extension staff, since only ideas are involved. Its gains go to farmers, not to seed companies, fertilizer salesmen, or pesticide promoters who have a financial stake in its spread. Indeed, by reducing farmers' demand for such inputs, and even eliminating this demand in many instances, SRI has evoked opposition in some circles. SRI would probably have spread faster if there had been some influential financial interests behind it. However, by its nature, the benefits of SRI accrue primarily to producers, and to consumers, and to the environment.

\section{Farmer Roles}

What went on at conferences and in journals was the visible, trackable part of the SRI innovation system. What has given the innovation 'legs' is much less evident and internationally-known: the response and initiative of farmers in many countries to the productivity and resource-saving opportunities which SRI opens up. Already when I visited $H$. M. Premaratna at his farm at Mellawalana, Sri Lanka, in March 2001, he said he had trained about 4,000 farmers in SRI methods, with his own resources, having gotten 10-15 tha yields with the new methods on his organically-managed farm after reading about SRI in the ILEIA newsletter. He had become a vocal champion of SRI, teaming up with a Sr. Asst. Secretary of Agriculture and the Deputy Minister of Agriculture, both of whom were championing SRI despite opposition from government researchers. Government officials and researchers who dismissed SRI at public meetings were challenged by Premaratna based on his own SRI experience and knowledge of agriculture. When I asked him why he put so much effort into spreading SRI, he replied: "I want to have rice paddies where my children can play safely." Premaratna attended the Sanya meeting in 2002, and subsequently, as a Sinhalese farmer, helped to introduce SRI into Tamil areas under LTTE control in the east coast of that ethnically-divided country on behalf of Oxfam/Australia (Figure 2).

In Cambodia, the first evaluation of SRI was in 1999 by the director of the NGO CEDAC, Dr. Koma Yang Saing, a trained agronomist who learned about SRI from the ILEIA article. He wanted to test the methods himself before recommending them to farmers. Even with good results, however, the next year he was able to persuade only 28 farmers to try out the methods on their own fields. One of them, Mey Som became an SRI activist who then introduced SRI to thousands of other farmers, as Premaratna had done in Sri Lanka, going village-to-village to spread knowledge of SRI (Figure 2).
His dedication got him fondly nicknamed "The Professor" by other farmers, and he has became a national leader in a farmer network with $>30,000$ family-members (Farmer-Nature Net) that has emerged with CEDAC support.

The Vietnamese woman farmer seen in Figure 1 above holding up rice plants is one of several farmer-fieldschool graduates in Dông Trù village who visited other farmers in their sub-district to promote wider use of SRI, displaying plants like this. They wanted to get reductions in farmers' water demand as well as to help them benefit from the new methods. There are no systematic data on farmer-to-farmer spread of SRI. However, in practically every country where SRI has begun, there are reports of such activity. To me this was early evidence that 'SRI works' since any innovation that farmers are willing to commit their own time and money to sharing with others must have considerable merit. ${ }^{6}$
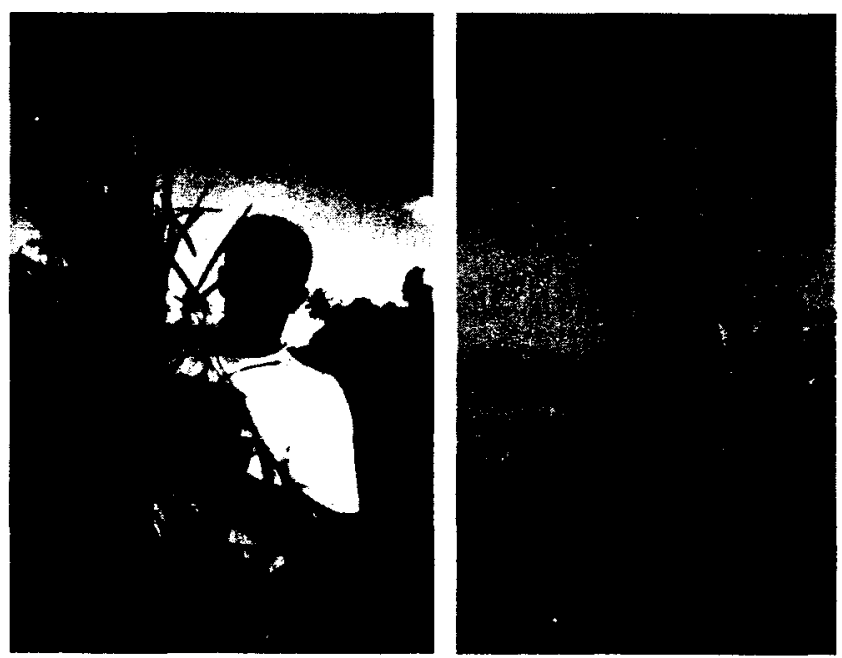

Figure 2. On left, H.M. Premaratna in Sri Lanka holding up an SRI plant for a picture that was later used on the cover of a German magazine on ecology; on right, Mey Som in Cambodia holding up two plants, SRI plant on left, that he used as visual aids in his village-to-village efforts to spread SRI use

\section{Electronic Communication}

A review of SRI dissemination methods has listed as the three main ones: (1) drawing on visual impacts of SRI (such as seen in the pictures here), (2) isolated and scattered efforts to popularize SRI, and (3) traditional SRI training programs (Meera, 2007). This is a fair enumeration as far as it goes, reflecting the extent to which SRI promotion has been a bottom-up process. However, it does not take enough account of the acceleration of SRI spread by (4) use of the internet, through e-mail and web pages.

SRI experience in Madagascar, however. A subsequent article (Barrett et al., 2004) modified the view first presented about SRI, however, it received many fewer citations in the literature than the first article did.

${ }^{6}$ Not only farmers have voluntarily assisted in the spread of SRI. While visiting Andhra Pradesh state in India in January 2004 , I recall a meeting with farmers in Kollur being introduced to an eminent surgeon from Hyderabad, Dr. D.L.N. Prasad, who had been spending the weekend in the villages around Kollur. He had been teaching farmers about SRI as a form of 'social work.' Because its benefits for farmers and the environment are so significant and evident, an unknown number of persons who are not themselves farmers have contributed to SRI's dissemination; but mostly SRI has been promoted by farmers and NGOs, and increasingly by extension services. 
Given the lack of support that SRI has had from the established scientific community, its spread would have been only $10-20 \%$ as fast by other means if there had not been any internet and e-mail connectivity. Capacity for electronic networking has meant that the 'gate-keeping' role previously played by recognized experts in any field, not just in rice science, has been greatly reduced. This can have some negative consequences, as unvetted and misleading information can be transmitted freely at the speed of light. On the other hand, valid and productive information can be spread just as fast, and if it proves beneficial, it will get a growing number of users and supporters. The scientific community is using these means itself internally, but it seems not to understand fully how much technological change is altering the precedence and power that existing institutional arrangements have given its members.

Most of the electronic communication regarding SRI has been among persons who are not the end-users of information, but rather NGO workers, scientists, program managers and others who are interested in new ideas and opportunities that can benefit farmers and rural communities and also the environment. It has been interesting to see how farmers in several countries, most notably India, have themselves been taking advantage of the internet to share their experience, ask questions, and disseminate their own innovations within the SRI network. The parallel paper on SRI spread notes three innovations by a farmer in Kadiramangalam village in the Cauvery Delta of southern India: a four-row weeder; a ridge-andfurrow method of crop establishment (direct-seeding/ñotill); and extension of SRI ideas to cotton. A fourth is a two-step transplanting method to deal with the heat and desiccation of local climate in the summer(http://ciifad.cornell.edu/sri/countries/india/kadira mangalam.html). Another farmer in Tamil Nadu who has been fine-tuning SRI methods for organic production, with excellent results, and who is training other farmers in the new methods, sent me the picture in Figure 3 below to show me his fine SRI crop.

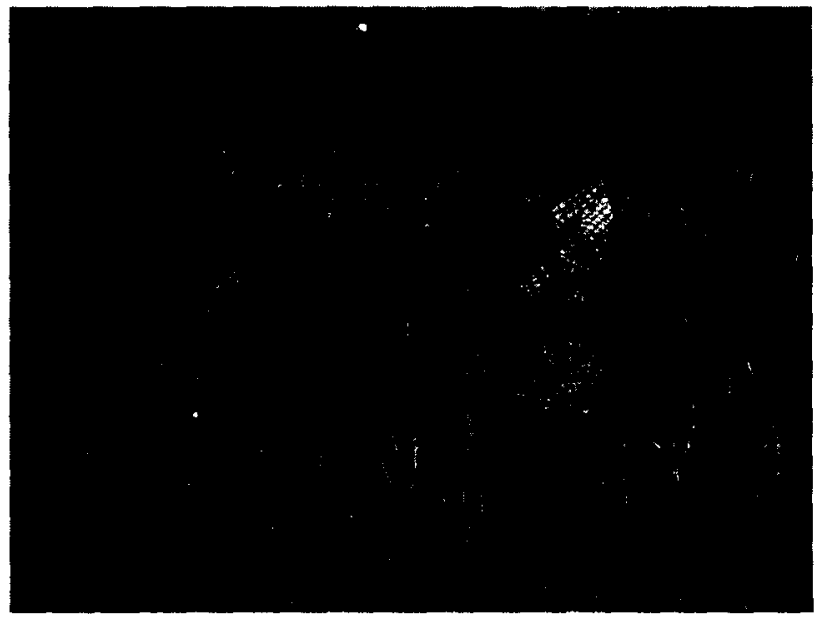

Figure 3. Moghan Raj Yadhav standing in his SRI paddy field in Nagipattinam village, Tamil Nadu, India
That a farmer would take such a picture in digital format and send it by e-mail to Cornell University, without any prior contact, is an indication of how, in this increasingly electronic era, farmers are becoming more versed and skilled in modern communication. The SRI home page that CIIFAD has maintained in cooperation with Association Tefy Saina(http://ciifad.comell.edu/sri) has probably been the single-most effective (and surely most cost-effective) part of the SRI innovation system. An excellent SRI site has been developed by WASSAN particularly for an Indian audience (www.wassan.org/sri), and it has recently been joined by a homepage operated with support from WWF (www.sri-india.net) for Indian SRI dissemination. It also serves the whole world, thanks to internet connectivity.

Within countries, the use of cell phones is also making a positive contribution to the diffusion of SRI knowledge and practice, particularly in the Philippines. CIIFAD supports two e-mail list-serves that are open to anyone interested: (a) periodic updates on what is happen ing with SRI around the world are available from SRI-UPDATE-L@cornell.edu and/or (b) interactive discussions on issues, problems and controversies in SRI practice as carried on SRI-RICE-L@cornell.edu Updates go also to everyone on the second list-serve, which is intended for persons who want to be involved with the advance of SRI concepts and practice. Either list-serve can be joined by writing to sri-rice@comell.edu

SRI networks in Philippines and Nepal have their own electronic discussion groups which are open to farmer participation, although most members are persons in intermediary roles for SRI dissemination: http://tech.groups.yahoo.com/group/SRI-Pilipinas/ and srinepal@yahoogroups.com The international scope of anything posted on the web is indicated by the fact that a SRI farmer group with 27 members has been formed in Ondo State of Nigeria based on a contact initiated with the SRI-Nepal web page (http://ciifad.cornell.edu/sri/ countries/nigeria/nigONDOsem0307.pdf). An electronic group recently started up in India for persons interested in SRI there (sriindia@googlegroups.com) already has 150 members. We have not been able to keep track of the spread of SRI knowledge through what is being called the blogosphere,' with collection and commentaries by all kinds of persons who keep track of and add to what is being communicated on the internet. When WWF released a new publication on SRI in Oct. 2007 (http://www.panda.org/about wwf/where we_work/europe/ publications/index.cfm?uNewsID $=114460$ ), within a few days, it had been publicized or commented on, mostly favorably, by more than 25 bloggers.

Since the SRI innovation system is not centrally initiated or controlled CIIFAD's role is facilitative rather than authoritative nobody knows the full extent of the electronic presence and contacts supporting SRI. As much as possible, participants' postings are cross-linked to each other's postings and to home pages. The whole enterprise has been remarkably free of competition, being motivated primarily by a spirit of curiosity and collaboration, with special concern that farmers' interests and, as much as possible, farmers' direct participation, will be furthered by the way in which electronic media are utilized.

\footnotetext{
${ }^{7}$ One reviewer of this paper commented that I should give more weight not just to the availability and functioning of electronic facilities, but to the way in which they have been used. He characterized this as being quickly responsive and very democratic, taking all queries and requests seriously, never knowing which ones will lead to some effective action on behalf of SRI. It is difficult to quantify and assess this, but it should be noted. How these electronic opportunities have been utilized has been somewhat novel.
} 
Generally speaking, the SRI dissemination effort has relied more on e-mail list-serves than on other web-based interactive features because in most developing countries, there are bandwidth limitations, and e-mail is the most widely accessible mode of communication. However, there are a number of other media, such as video and extension materials that can be uploaded onto the Comell server, and persons with good internet access can view or download them. We have posted videos abut SRI in Iraq, Cuba, Indonesia and Thailand on the SRI website, making them accessible worldwide as well as SRI manuals in more than 10 languages. One member of the SRI network has posted a video on SRI experience in northeastern Thailand on YouTube

(http://www.youtube.com/watch?v=b31LgNMu-hg).

Given bandwidth constraints that many persons in the SRI community of practice are faced with, CIIFAD has also provided CDs/DVDs about SRI to support training activities in a number of countries as a reliable and lowcost means of communication. This can complement the web-based distribution of these materials, such as the introduction to SRI and training video prepared under auspices of DISIMP in Indonesia (http://www.srivideo.zoomshare.com/) utilizing step-bystep material from field documentation as well as an endorsement of SRI by the President of Indonesia, Dr. S.B. Yudhoyono in July 2007.

\section{Organizational Coalitions for SRI}

A consistent theme guiding the SRI innovation system has been participatory involvement, stressing diversity and complementarity. As noted above, SRI has been a civil-society innovation, taking a view of what constitutes civil society. This includes the participation of state-institution actors who become engaged on the basis of their interest, expertise and values rather than their authority. Usually in any country or state, SRI initiative has come from one sector or another, with leadership for SRI passing informally to whichever institution takes the initiative to get SRI started. There is seldom any formal designation of leadership roles or responsibility. The ethos has been that working on and with SRI remains open to participation from any and all sectors: from NGOs, from universities, from research institutions, from government agencies, from farmer organizations, and often from the private sector. This is characterized in the following table which summarizes SRI initiative and involvement for 24 countries (Figure 4).

Because SRI has the nature of a 'public good' rather than a 'private good,' private-sector involvement has been less than that of other sectors. But in Indonesia, for example, private-sector push has been crucial for the rapid expansion in that country; and in Bangladesh, Syngenta became one of the earliest backers of SRI. (SRI methods are beneficial for seed multiplication, a major activity of Syngenta Bangladesh Co. Ltd.) SRI is 'open-access,' like Linux software, and it remains in the public domain, not appropriable for exclusive private benefit.

The figure on the next page gives an indicative listing of initiators (bolded) and supporters of SRI dissemination. The full extent cannot be captured in single table, or in any one mind. This table portrays the diversity of actors who have played roles in introducing SRI, or who have joined in the effort once SRI merits are seen. The last nine countries noted are still in their early stages with SRI.

The role of individuals becomes very apparent because in almost all cases the initial interest and effort emanated from one person or a few individuals. In some cases (asterisked), involvement remained only or essentially individual; but usually the institutions or organizations became to varying degrees 'infected' by SRI, considering SRI as a benign, even beneficent infection. SRI experience clearly supports Robert Chambers' argument (1983) about the importance of 'the personal factor' in rural development.

Growing out of the inductive creation of coalitions of diverse partners who work on and for SRI has been the emergence of what can be called learning alliances (Prasad et al., 2007). In June 2007, a group of government, NGO, research, farmer and other participants in a SRI 'experience-sharing' session for Orissa state of India hit upon this concept in its deliberations, finding out later that the term had already been used in the organization-theory and innovation-systems literature (Lundy et al., 2005, drawing from Bawden, 1994), for the same good reasons.

The SRI innovation system has functioned best where a diverse set of actors coming from heterogeneous institutional bases have come together to share experience and to learn from and with each other. They have not created a grand coordinated program, with central direction, but rather a synchronized, mutually reinforcing effort, often with agreements to cooperate and even join together in conducting certain programs. The structures are more informal than formal, although some explicit coordinating bodies have been created, e.g., in Bangladesh. More common are the kinds of networks functioning in Nepal and Philippines. In countries as large and heterogeneous as China and India, such bodies function better at the provincial or state level, either formally or informally. The emerging organizational framework in Orissa state is the first of its kind in India (Prasad et al., 2007). It may become a model for others as civil society, writ large, seeks to engage more functionally with state institutions and to step up the pace of SRI expansion. 


\begin{tabular}{|c|c|c|c|c|c|c|}
\hline Country & $\begin{array}{l}\text { Public } \\
\text { Agencies }\end{array}$ & $\begin{array}{l}\text { Research } \\
\text { Institutes }\end{array}$ & Universities & NGOs & $\begin{array}{l}\text { Farmer } \\
\text { Associations }\end{array}$ & Private Sector/ Donors \\
\hline BANGLADESH & $\begin{array}{l}\text { Dept. of } \\
\text { Agricultural } \\
\text { Extension }\end{array}$ & $\begin{array}{l}\text { BD Rice } \\
\text { Research } \\
\text { Institute } \\
\text { [ambivalent] }\end{array}$ & $\begin{array}{l}\text { Natl. } \\
\text { Agricultural } \\
\text { University }\end{array}$ & $\begin{array}{l}\text { CARE/BD, } \\
\text { SAFE, POSD, } \\
\text { BRAC, et al. }\end{array}$ & & $\begin{array}{l}\text { Syngenta BD Co. Ltd. } \\
\text { Oxfam/GB } \\
\text { ActionAid }\end{array}$ \\
\hline CAMBODIA & $\begin{array}{l}\text { Ministry of } \\
\text { Agriculture, } \\
\text { Forestry \& } \\
\text { Fish. } \\
\text { SRI } \\
\text { Secretariat }\end{array}$ & $\begin{array}{l}\text { CARDI } \\
\text { [mostly } \\
\text { resistant] }\end{array}$ & $\begin{array}{l}\text { Royal } \\
\text { University of } \\
\text { Agriculture }\end{array}$ & $\begin{array}{l}\text { CEDAC + } \\
\text { more than } 30 \\
\text { other NGOs }\end{array}$ & $\begin{array}{l}\text { Farmer-Nature } \\
\text { Network, wjth } \\
\text { CEDAC }\end{array}$ & $\begin{array}{l}\text { GTZ, JICA, } \\
\text { Oxfam/America, and } \\
\text { others }\end{array}$ \\
\hline CHINA & $\begin{array}{l}\text { Prov. Depts. of } \\
\text { Agriculture: } \\
\text { Zhejiang, } \\
\text { Sichuan, et al. } \\
\text { [promotion] } \\
\text { National } \\
\text { Ministry of } \\
\text { Agriculture } \\
\text { [endorsement] }\end{array}$ & $\begin{array}{l}\text { China Natl. } \\
\text { Rice Res. } \\
\text { Institute; } \\
\text { Sichuan } \\
\text { Acad. Agr. } \\
\text { Sciences; } \\
\text { China Natl. } \\
\text { Hybrid } \\
\text { Rice R\&D } \\
\text { Center }\end{array}$ & $\begin{array}{l}\text { Nanjing } \\
\text { Agricultural } \\
\text { University, } \\
\text { Northeast } \\
\text { Agricultural } \\
\text { University, } \\
\text { Sichuan } \\
\text { Agricultural } \\
\text { University, et } \\
\text { al. }\end{array}$ & & $\begin{array}{l}\text { Some farmer } \\
\text { associations at } \\
\text { local levels }\end{array}$ & $\begin{array}{l}\text { Meishan Seed Co., } \\
\text { Sichuan }\end{array}$ \\
\hline INDIA & $\begin{array}{l}\text { Ministry of } \\
\text { Agriculture, } \\
\text { State Dept. of } \\
\text { Agriculture in } \\
\text { TN and } \\
\text { Tripura } \\
\text { KVKs (agric. } \\
\text { ext. centers) }\end{array}$ & $\begin{array}{l}\text { Indian } \\
\text { Council for } \\
\text { Agric. Res., } \\
\text { DRR. } \\
\text { DRD.. } \\
\text { NCAP }\end{array}$ & $\begin{array}{l}\text { AP Agric. } \\
\text { Univ., TN } \\
\text { Agric. Univ., } \\
\text { Xavier Inst. of } \\
\text { Management, } \\
\text { Jammu } \\
\text { AUS\&T and } \\
\text { others }\end{array}$ & $\begin{array}{l}\text { WASSAN, } \\
\text { PSI, PRADAN, } \\
\text { AME, } \\
\text { Timbuktu } \\
\text { Collective and } \\
\text { many others }\end{array}$ & $\begin{array}{l}\text { Local govt. } \\
\text { bodies in } \\
\text { Tripura, AP } \\
\text { farmers' } \\
\text { association. } \\
\text { TN organic } \\
\text { farmers. } \\
\text { women's self- } \\
\text { help groups in } \\
\text { Orissa }\end{array}$ & $\begin{array}{l}\text { WWF, SDTT, AP Rice } \\
\text { Millers' Association } \\
\text { [latter no longer } \\
\text { active] }\end{array}$ \\
\hline INDONESIA & $\begin{array}{l}\text { Dept. of } \\
\text { Irrigation (PU) } \\
\text { Dept. of } \\
\text { Agriculture }\end{array}$ & $\begin{array}{l}\text { AARD Rice } \\
\text { Research } \\
\text { Institute, } \\
\text { Sukamandi } \\
\text { [ambivalent] }\end{array}$ & $\begin{array}{l}\text { Agricultural } \\
\text { Univ. at Bogor } \\
\text { (IPB), } \\
\text { Universitas } \\
\text { Andalas } \\
\text { and others } \\
\end{array}$ & $\begin{array}{l}\text { Aliksa Organic } \\
\text { SRI Consult, } \\
\text { MEDCO } \\
\text { Foundation* }\end{array}$ & $\begin{array}{l}\text { Farmer Field } \\
\text { Schools, } \\
\text { working with } \\
\text { the Field } \\
\text { Foundation } \\
\text { (IPM Program) } \\
\end{array}$ & $\begin{array}{l}\text { Nippon Koei TA } \\
\text { team* (Japan) } \\
\text { PT Sampoerna }\end{array}$ \\
\hline LAOS & & $\begin{array}{l}\text { National } \\
\text { Rice Prog. } \\
\text { (IRRI) }\end{array}$ & & Oxfam/Australia & & $\begin{array}{l}\text { JOVC } \\
\text { [recent] }\end{array}$ \\
\hline MYANMAR & & & & $\begin{array}{l}\text { Metta } \\
\text { Development } \\
\text { Foundation }\end{array}$ & $\begin{array}{l}\text { Farmer Field } \\
\text { Schools. with } \\
\text { training by } \\
\text { Metta }\end{array}$ & \\
\hline NEPAL & $\begin{array}{l}\text { District Agric. } \\
\text { Exten. Office, } \\
\text { Morang* }\end{array}$ & ICIMOD & & $\begin{array}{l}\text { Intl. Nepal } \\
\text { Fellowship, } \\
\text { SAPPROS, } \\
\text { other NGOs }\end{array}$ & & $\begin{array}{l}\text { NEDECO team; } \\
\text { Poverty Allev. Fund } \\
\text { (World Bank funded) }\end{array}$ \\
\hline PAKISTAN & $\begin{array}{l}\text { Punjab Dept. } \\
\text { of Agric. } \\
\text { Water Mgmt } \\
\text { Wing } \\
\end{array}$ & $\begin{array}{l}\text { ICIMOD } \\
\text { [early start, } \\
\text { dropped } \\
\text { out] } \\
\end{array}$ & $\begin{array}{l}\text { Agricultural } \\
\text { University at } \\
\text { Faisalabad }\end{array}$ & & & \\
\hline PHILIPPINES & $\begin{array}{l}\text { National Irrig. } \\
\text { Administration, } \\
\text { Department. of } \\
\text { Agriculture } \\
\text { (ATI) }\end{array}$ & $\begin{array}{l}\text { Philippine } \\
\text { Rice Res. } \\
\text { Institute } \\
\text { (PhilRice) }\end{array}$ & $\begin{array}{l}\text { U of Philippines } \\
\text { at Los Baños. } \\
\text { Leyte State } \\
\text { Univ. } \\
\text { and others }\end{array}$ & $\begin{array}{l}\text { Phil. Rural } \\
\text { Reconstruction } \\
\text { Movement, } \\
\text { SITMo, others }\end{array}$ & $\begin{array}{l}\text { PABINHI, } \\
\text { MASIPAG, } \\
\text { Organic farmers }\end{array}$ & \\
\hline SRI LANKA & $\begin{array}{l}\text { Ministry of } \\
\text { Agriculture* } \\
\text { [ambivalent] }\end{array}$ & $\begin{array}{l}\text { Rice Res. } \\
\text { Institute } \\
\text { [opposed] }\end{array}$ & $\begin{array}{l}\text { Ruhunu } \\
\text { University }\end{array}$ & Oxfam/Australia & $\begin{array}{l}\text { Mellawalana } \\
\text { Organic } \\
\text { Farming } \\
\text { Center* } \\
\end{array}$ & $\begin{array}{l}\text { Gemi Diriya } \\
\text { Foundation (World } \\
\text { Bank) }\end{array}$ \\
\hline THAILAND & $\begin{array}{l}\text { Dept. of } \\
\text { Agriculture } \\
\text { [recent] }\end{array}$ & & $\begin{array}{l}\text { Chiangmai } \\
\text { Univ. (MCC),* } \\
\text { Asian Inst. of } \\
\text { Technol. }\end{array}$ & $\begin{array}{l}\text { McKean Rehab } \\
\text { Center, }{ }^{*} \text { CCHD, } \\
\text { and others }\end{array}$ & & \\
\hline VIETNAM & National IPM & Vietnam & Thai Nguyen & Centre for Sust. & Farmer Field & Oxfam/America, JOVC \\
\hline
\end{tabular}




\begin{tabular}{|c|c|c|c|c|c|c|}
\hline & Program & $\begin{array}{l}\text { Academy } \\
\text { of Agric. } \\
\text { Sciences }\end{array}$ & $\begin{array}{l}\text { Univ., Hanoi } \\
\text { Agric. Univ. }\end{array}$ & Rural Dev. & $\begin{array}{l}\text { Schools with } \\
\text { Natl. IPM Prog. }\end{array}$ & [recent] \\
\hline MADAGASCAR & $\begin{array}{l}\text { Ministry of } \\
\text { Agriculture }\end{array}$ & FOFIFA* & $\begin{array}{l}\text { University of } \\
\text { Antananarivo }\end{array}$ & $\begin{array}{l}\text { Assoc. Tefy } \\
\text { Saina + others }\end{array}$ & $\begin{array}{l}\text { Kolo Harena } \\
\text { Federation } \\
\end{array}$ & $\begin{array}{l}\text { USAID, MCC, CRS, } \\
\text { ADRA }\end{array}$ \\
\hline$\overline{\text { CUBA }}$ & $\begin{array}{l}\text { Ministry of } \\
\text { Sugar* } \\
\text { Arroz Popular }\end{array}$ & $\begin{array}{l}\text { Rice Res. } \\
\text { Inst. (IIA), } \\
\text { INRA }\end{array}$ & & $\begin{array}{l}\text { Cuban Council } \\
\text { of Churches }\end{array}$ & $\begin{array}{l}\text { Cooperatives, } \\
\text { Urban } \\
\text { Agriculture } \\
\text { movement }\end{array}$ & \\
\hline SIERRA LEONE & & & & World Vision & & \\
\hline PERU & & & $\begin{array}{l}\text { Natl. Inst. of } \\
\text { Engineering* }\end{array}$ & PRO-A & & \\
\hline GAMBIA & & $\begin{array}{l}\text { National } \\
\text { Agric. Res. } \\
\text { Council* }\end{array}$ & & & & \\
\hline GUINEA & & & & & & $\begin{array}{l}\text { China Natl. Hybrid } \\
\text { Rice R\&D Center }\end{array}$ \\
\hline ZAMBIA & & & & & $\begin{array}{l}\text { Esek Farmers } \\
\text { Coop. Society }\end{array}$ & \\
\hline IRAN & & $\begin{array}{l}\text { Haraz } \\
\text { Technology } \\
\text { Dev. \& Ext. } \\
\text { Center }{ }^{\star} \\
\end{array}$ & & & & \\
\hline IRAQ & & $\begin{array}{l}\text { Al- } \\
\text { Mishkhab } \\
\text { Rice Res. } \\
\text { Station* } \\
\end{array}$ & & & & \\
\hline BHUTAN & . & & $\begin{array}{l}\text { Royal Univ. of } \\
\text { Bhutan, } \\
\text { College of Nat. } \\
\text { Res." }\end{array}$ & & & \\
\hline AFGHANISTAN & & & & & & Afg Khan Foundation \\
\hline EGYPT & & $\begin{array}{l}\text { Natl. Rice } \\
\text { Research \& } \\
\text { Training } \\
\text { Ctr, Sakha } \\
\end{array}$ & & & & \\
\hline ECUADOR & & & & FUNDEC & & \\
\hline COSTA RICA & & & & $\begin{array}{l}\text { Oscar } \\
\text { Moreno* }\end{array}$ & & \\
\hline RWANDA & $\begin{array}{l}\text { IFAD } \\
\text { (PAPSTA } \\
\text { project) } \\
\end{array}$ & & & $\begin{array}{l}\text { Union of Rice } \\
\text { Cooperatives } \\
\text { of Rwanda }\end{array}$ & & \\
\hline GHANA & $\begin{array}{l}\text { Ghana } \\
\text { Irrigation } \\
\text { Development } \\
\text { Centre } \\
\end{array}$ & $\begin{array}{l}\text { Crop } \\
\text { Research } \\
\text { Inst. }\end{array}$ & & $\begin{array}{l}\text { Kwabena } \\
\text { Broni* }\end{array}$ & & $\begin{array}{l}\text { Nippon Koei } \\
\text { consulting firm }\end{array}$ \\
\hline MALAYSIA & FELCRA & MARDI & $\begin{array}{l}\text { National Univ. } \\
\text { of Malaysia } \\
\text { (UKM) }\end{array}$ & & & $\begin{array}{l}\text { Private consulting } \\
\text { group }\end{array}$ \\
\hline
\end{tabular}

*Individual involvement primarily; of course, often institutional involvement was started by an individual.

Figure 4. A Mapping of the SRI Innovation System in Different Counties (leadership indicated in bold)

\section{Operational Challenges and Technical Constraints for Mainstreaming SRI}

Resistance to SRI probably reached its peak in 2004, with a number of negative article published against SRI the agronomic literature, even though these could have not have withstood peer-review by persons who are knowledgeable about SRI. Articles reporting SRI results, some of them spectacular, with large multi-year data sets, using standfard agronomic methodologies, are starting to get into the peer-reviewed literature (e.g., Ceesay et al., 2006; Kabir and Uphoff, 2007; Namara et al., 2007; Sato and Uphoff, 2007; Satyanarayana et al., 2006; Sinha and Talati, 2007).

Probably the most important factor starting to turn opinion in SRI's favor is that the three largest riceproducing countries, which grow and consume $>60 \%$ of the world's rice, are now officially supporting the dissemination of SRI while continuing research and evaluation. 
- In China, $>400,000$ hectares (6.5 million mu) are under SRI management in the provinces of Sichuan and Zhejiang as of 2007. This is up from $<10,000$ hectares three years earlier and includes $1 / 3$ of the total rice area in Zhejiang province (http://ciifad.cornell.edu/sri/countries/china/cnntutrep 0807.pdf). SRI methods were recommended already in 2004 by the central government's Ministry of Agriculture to Provincial Departments of Agriculture, responsible for extension within the Chinese system.

- In India, the central government plans to support extension of SRI to 5 million hectares over the next five years under its National Food Security Mission. The State of Tripura, where SRI was used by $<1,000$ farmers just two years ago, now has $>70,000$ farmers practicing SRI with plans to continue this rapid expansion

(http://ciifad.cornell.edu/sri/countries/india/inntutrep 1007.pdf). SRI trials, demonstrations and/or extension activities are going on in $>20$ states and territories in India. The Minister of Agriculture for Tamil Nadu state says that 420,000 hectares, $20 \%$ of the state's rice area, is under SRI management (http://www.thehindu.com/2008/01/01/stories/20080 10153180300.htm).

- $\quad$ In Indonesia, the President S.B. Yudhoyono, who has a $\mathrm{PhD}$ in agriculture from the Agricultural University at Bogor (IPB), has endorsed SRI publicly, calling upon the Ministry of Agriculture to promote it, and particularly its organic version, suggesting that SRI can be a corrective to the Green Revolution (http://ciifad.cornell.edu/SRI/countries/indonesia/ind opresident073007.pdf). For a video of President Yudhoyono's statement, see: http://www.srivideo.zoomshare.com/

- In Southeast Asia, SRI promotion has been incorporated into the Cambodian National Development Plan for 2006-2010, with the Ministers of Agriculture and of Environment personally promoting the new methods during rural visits (http://ciifad.comell.edu/sri/countries/cambodia/camb trntu 106.pdf) and the Prime Minister also asking farmers to use it. In Vietnam, the Ministry of Agriculture and Rural Development designated SRI as a 'technology advance' in April 2007 and will now provide financial support for research and extension (http://ciifad.cornell.edu/sri/countries/vietnam/vnntut Irpt0707.pdf).

With these kinds of official action, based on field and experimental results, the scientific resistance to SRI cannot be sustained for much longer. IRRI and CIIFAD have agreed to undertake a jointly-planned and jointlyimplemented evaluation of SRI methods, comparing them with what IRRI scientists consider 'best management practices.' This will involve several national agricultural research systems in a collaborative effort to resolve scientific disagreements about SRI's merits and suitability. The most important question for SRI proponents is becoming how to support scaling-up that is effective, equitable and sustainable.
Because SRI is not dependent on the purchase or distribution of external inputs - involving only the diffusion of knowledge, skill and confidence -- its dissemination has unconventional dynamics and conditions, and it cannot be a literal model for other innovation systems. The biggest challenge for scaling up will be now to avoid the kind of top-down pressures and impositions typical of large-scale adoption campaigns. This has so far been minimized. The extension service of Tripura State in India has, in my observation, been exemplary in maintaining an appropriate spirit of innovation and volunteerism, working with and through local government bodies (http://ciifad.cornell.edu/sri/countries/india/inntutrep 1007. pdf). It cannot be reiterated often enough that ' $S R I$ is not a technology,' and thus it needs to be presented and spread as a set of ideas, not involving 'something new' so much as making changes in present practice.

The main obstacles to SRI adoption remain mental and attitudinal, as farmers who have taken up SRI themselves continually attest. An initial barrier is laborintensity, while the methods are being learned (Moser and Barrett, 2003). But once farmers acquire skill with and confidence in the methods, more and more evaluations show SRI to be labor-neutral or even become labor-saving (Uphoff, 2007, Section 3.6).

The most objective constraint on SRI adoption is water control, being able to manage irrigation systems sufficiently to provide reduced but reliable amounts of water on an intermittent basis. Where fields are low-lying and continuously submerged or mostly saturated, SRI methods will not produce their best results. Water control is relative, not an absolute, requirement. Farmers in a number of countries have been adapting SRI concepts to rainfed/unirrigated rice production, as reported in the companion paper.

Pest control can also be a requirement for greatest success. Aerobic soil conditions usually reduce pest and disease problems, but they can encourage some pests such as leaf folder or root-feeding nematodes. Evaluations - and farmer reports - have shown that on balance there is a reduction in pest and disease incidence (http://ciifad.cornell.edu/sri/countries/vietnam/vndungipmr pt06.pdf). Integrated pest management practices are always recommended to be followed with SRI. As suggested above, the most important factors limiting SRI uptake are subjective - i.e., mental barriers - with the objective factor of water control also important. The latter can usually but not always be accomplished with appropriate investments in irrigation hardware or software (organization). The value of the water that is saved with SRI can justify considerable investment in whatever hardware and/or software may be needed.

Labor constraints are usually a transitory limitation, although timely and effective (soil-aerating) weeding may be difficult for many farmers to do. This has prompted farmer innovations in weeder design, including motorization, as well as modified methods of crop establishment that are labor-saving and profit-increasing. In many settings, there may not be enough available biomass, beyond the recycling of rice straw, to meet soil nutrient needs with compost. In this case, chemical 
fertilizer can be used with the other SRI methods. However, with innovative efforts, the supply of biomass can usually be considerably enlarged. There is much scope for innovation in the tools and implements needed to make the collection, transport and processing of biomass very labor-efficient - cutters, shredders, better wheelbarrows, etc.

It needs to be continually restated that SRI is still a methodology 'under construction,' being continuously modified and improved by the efforts particularly of farmers. It is premature to try to make any conclusive characterization of SRI as a system of and for innovation, because this system is itself in the process of formulation and reformulation. As such, it offers an opportunity for students of 'innovation systems' to learn from a system, albeit a rather unique one, that is in the process of emergence.

The story of SRI innovation is still being written, and will surely continue for quite a few years to come. There are internal debates going on within the SRI network, characteristically in a rather diffuse way, about the extent to which SRI is or should be a fully 'organic' innovation; whether it should or can be taken up by larger and not just small-scale farmers, and whether it can or should be limited to the latter; whether its becoming labor-saving is a good thing or not, i.e., whether it is more important to promote employment opportunities or to lower the price of staple food for the poor.

At the $2^{\text {nd }}$ all-India national SRI symposium held in Agartala in October, 2007, there was lively debate, especially involving farmer perspectives, on whether or not SRI should be promoted with government subsidies. Arguments over whether or not subsidies are necessary intersected with whether these should be given as a matter of fairness, since so many other things are subsidized these days. There have surely been some missed opportunities, and some missteps, stemming from the decentralized nature of the SRI system of innovation. But so far there seem to be more-than-offsetting advantages, such as making the innovation impossible to halt through 'authoritative' attacks on it. One cannot say when it will be appropriate, or even possible, to make a final judgment on the merits of the innovation system that has emerged, even if there is less and less debate on the merits of the innovation itself.

\section{REFERENCES}

Barrett, C. B., C. M. Moser, O. V. McHugh, and J. Barison. 2004. Better technology, better plots or better farmers? Identifying changes in productivity and risk among Malagasy rice farmers. American Journal of Agricultural Economics, 86: 869-888.

Bawden, R. 1994. Creating learning systems: A metaphor for institutional reform for development in $\mathrm{I}$. Scoones and J. Thompson eds., Beyond Farmer First: Rural People's Knowledge, Agricultural Research and Extension Practice,' Intermediate Technology Publications, London, 258-263.
Berkelaar, D. 200I. SRI -- The System of Rice Intensification: Less Can Be More, ECHO Development Notes, No. 70. http://www.echotech.org/network/modules.php?name $=$ News $\&$ file $=$ article $\&$ sid $=461$

Cao, W. X., Jiang, S. Wang and Y. C. Tian. 2002. Physiological characteristics of rice grown under different water management systems in B. Bouman et al. eds., Water-Wise Rice Production, IRRI, Los Bafios.

Ceesay, M. 2002. Experiments with the System of Rice Intensification in the Gambia in N. Uphoff et al. eds., Assessments of the System of Rice Intensification, 5657 http://ciifad.cornell.edu/sri/proc 1/sri 13.pdf

Ceesay, M., W. S. Reid, E. C. M. Fernandes, and N. Uphoff. 2006. The effects of repeated soil wetting and drying on lowland rice yield with System of Rice Intensification SRI methods. International Journal of Agricultural Sustainability, 4: 5-14.

Chambers, R. 1983. Rural Development: Putting the Last First. Harlow, London.

Chen H. Z., D. F. Zhu, L. B. Rao, X. Q. Lin and Y. P. Zhang 2006. Effects of SRI technique on population quality after heading stage and yield formation in rice. Journal of Huazhong Agricultural University, 25: 483-487.

Culman, S. W., J. M. Duxbury, J. L. Lauren, and J. E. Thies. 2005. Microbial community response to soil solarization in Nepal's rice-wheat cropping system. Soil Biology and Biochemistry, 38: 3359-3371.

DeDatta, S. K. 1981. Principles and Practices of Rice Production, John Wiley \& Sons, New York.

Dobermann, A. 2004. A critical assessment of the system of rice intensification. Agricultural Systems, 79: 261281 .

Gani, A., T. S. Kadir, A. Jatiharti, I. P. Wardhana, and I. Lal. 2002. The System of Rice Intensification in Indonesia,' in N. Uphoff et al. eds., Assessments of the System of Rice Intensification. 58-63. http://ciifad.comell.edu/sri/procl/sri 14.pdf

Gomez, K. A. and S. K. DeDatta 1971. Border effects in rice experimental plots. Experimental Agriculture, 7: 87-97.

Guerra, L. C., S. I. Bhuiyan, T. P. Thuong, and R. Barker. 1998. Producing More Rice with Less Water in Irrigated Systems. SWIM Paper 5, International Water Management Institute, Colombo.

Horie, T., T. Shiraiwa, K. Homma, K. Katsura, S. Maeda, and $H$. Yoshida. 2005. Can yields of lowland rice resume the increases that they showed in the 1980 s?. Plant Production Science, 8: 257-272.

Laulanié, H. 1993. Le système de riziculture intensive malgache. Tropicultura, 11:110-114. 
Laulanié, H. 2003. Le Riz à Madagascar: Un dèveloppement en dialogue avec les paysans, Editions Karthala, Paris.

Lin, X. Q., W. J. Zhou and D. F. Zhu. 2005. The photosynthetic rate and water use efficiency of leaves at different position at panicle initiation stage under the System of Rice Intensification. Chinese Journal of Rice Science, 19: 200-206 as (In Chinese).

Lu, X. M., Q. Huang and H. Z. Liu. 2006. Research of some physiological characteristics under the System of Rice Intensification. Journal of South China Agricultural University, 27: 5-7.

Lundy, M., M. V. Gottret, and J. Ashby. 2005. Learning Alliances: An Approach to Building MultiStakeholder Innovation Systems. ILAC Brief, 8: 4.

Makarim, A. K., V. Balasubramaniam, Z. Zaini, I. Syamsiah, I. G. P. A. Diratmadja, Handoko, Arafah, I. P. Wardana, and A. Gani. 2002. System of Rice Intensification: Evaluation of seedling age and selected components in B. Bouman et al. eds., WaterWise Rice Production, IRRI, Los Baños.

McDonald, A. J., P. R. Hobbs, and S. J. Riha. 2006. Does the system of rice intensification outperform conventional best management?. A synopsis of the empirical record,' Field-Crops Research, 96: 31-36.

Meera, S. 2007. E-Learning for SRI: Open and distance learning modules. Powerpoint presentation for $2^{\text {nd }}$ National SRI Symposium, Agartala, Oct. 3-5, from Directorate of Rice Research, Indian Council for Agricultural Research, Hyderabad.

Mishra, A., M. Whitten, J. W. Ketelaar, and V. M. Salokhe. 2006. The System of Rice Intensification SRI: A challenge for science, and an opportunity for farmer empowerment towards sustainable agriculture. International Journal of Agricultural Sustainability, 4: 193-212.

Moser, C. M. and C. B. Barrett. 2003. The disappointing adoption dynamics of a yield-increasing, low external-input technology: The case of SRI in Madagascar. Agricultural Systems, 76: 1085-1100.

Namara, R. E., I. Hussain, D. Bossio, and S. Verma. 2007. Innovative land and water management approaches in Asia: Productivity impacts, adoption prospects and poverty outreach. Irrigation and Drainage, 56: 335348.

Prasad, S. C. 2006. System of Rice Intensification in India: Innovation History and Institutional Challenges, WWF-ICRISAT Dialogue on Water, Food and Environment, Patancheru, Hyderabad http://www.wassan.org/sri/documents/Shambu SRI.p df

Prasad, S. C., K. Beumer and D. Mohanty. 2007. Towards a Learning Alliance: SRI in Orissa, Xavier Institute of Management, Bhubaneswar, and WWF-ICRISAT Dialogue on Water, Food and Environment, Patancheru
http://ciifad.comell.edu/SRI/countries/india/SRlinOri ssa07.pdf

Rabenandrasanana, J. 1999. Revolution in rice intensification in Madagascar,' LEISA Newsletter, 15. http://www.google.com/search?hl=en\&q=Rabenandr asana+LEISA.

Ramasamy, S., H. F. M. ten Berge, and S. Purushothaman. 1997. Yield formation in rice in response to drainage and nitrogen application. Field Crops Research, $51: 65-82$.

Randriamiharisoa, R. 2002. Research results on biological nitrogen fixation with the System of Rice Intensification in N. Uphoff et al. eds., Assessments of the System of Rice Intensification, 148-158 http://ciifad.cornell.edu/sri/proc1/sri 33.pdf

Randriamiharisoa, R., J. Barison, and N. Uphoff. 2006. Soil biological contributions to the System of Rice Production in N. Uphoff et al. eds., Biological Approaches to Sustainable Soil Systems, 409-424, CRC Press, Boca Raton, FL.

Ravindran, A. 2007. Promotional Policies for SRI. Powerpoint presentation to $2^{\text {nd }}$ National SRI Symposium, Agartala, October 3-5.

Romani, M., B. Borghi, R. Alberici, G. Delogu, J. Hesselbach, and F. Salamini. 1993. Intergenotypic competition and border effect in bread wheat and barley,' Euphytica, 69: 19-31.

Sato, K. and K. Takahashi. 1983. An analysis of the border effect on rice paddy fields. Japanese Journal of Crop Science, 52: 168-176.

Sheehy, J. E., S. Peng, A. Dobermann, P. L. Mitchell, A. Ferrer, J. C. Yang, Y. B. Zou, X. H. Zhong, and J. L. Huang. 2004. Fantastic yields in the system of rice intensification: fact or fallacy?. Field Crops Research, 88: 1-8.

Sinclair, T. R. 2004. Agronomic UFOs waste valuable scientific resources,' Rice Today, 3: 43.

Sinclair, T. R. and K. G. Cassman. 2004. Agronomic UFOs. Field Crops Research, 88: 9-10.

Stoop, W., N. Uphoff, and A. Kassam. 2002. A review of agricultural research issues raised by the System of Rice Intensification SRI from Madagascar: Opportunities for improving farming systems for resource-poor farmers. Agricultural Systems, 71: 249 . 274.

Surridge, C. 2004. Feast or famine?. Nature 428: 360-361.

Tao, S. S. and J. Ma. 2003. Improvement of the System of Rice Intensification SRI and its application in medium hybrid rice of the double cropping system. Hybrid Rice, 18: 47-48.

Tao, L. X., X. Wang, and S. K. Min. 2002. Physiological effects of SRI methods on the rice plant in N. Uphoff et al. eds., Assessments of the System of Rice Intensification, 132-136 http://ciifad.comell.edu/sri/procl/sri 29.pdf 
hiyagarajan, T. M. 2002. Experiments with a modified System of Rice Intensification in India in N. Uphoff et al., eds., Assessments of the System of Rice Intensification $137-139$ http://ciifad.cornell.edu/SRl/procl/sri 30.pdf

phoff, N. 1999. Agroecological implications of the System of Rice Intensification SRI in Madagascar. Environment, Development and Sustainability, 1: 3-4.

Iphoff, N. 2003. Higher yields with fewer external inputs? The System of Rice Intensification and potential contributions to agricultural sustainability. International Journal of Agricultural Sustainability, 1: 38-50.

Iphoff, N. 2005. The development of the System of Rice Intensification in J. Gonsalves et al. eds., Participatory Research and Development for Sustainable Agriculture and Rural Development, Vol. 3, 119-125, International Potato CenterUPWARD and International Development Research Centre, Ottawa.

Jphoff, N. 2007. Reducing the vulnerability of rural households through agroecological practice: Considering the System of Rice Intensification SRI, Mondes en Développement, 35:4.

Jphoff, N., E. C. M. Fernanides, L. P. Yuan, J. Peng, S. Rafaralahy, and J. Rabenandrasana. eds. 2002 Assessments of the System of Rice Intensification: Proceedings of an International Workshop. April 1-4, 2002, Sanya, China, Cornell International Institute for Food, Agriculture and Development, Ithaca, NY http://ciifad.cornell.edu/sri/procl/index.html

Jphoff, N. and R. Randriamiharisoa. 2002. Reducing water use in irrigated rice production with the Madagascar System of Rice Intensification in B. Bouman et al. eds., Water-Wise Rice Production, IRRI, Los Baños.

Wang, S. H., W. X. Cao, D. Jiang, T. B. Dai, and Y. Zhu. 2002. Physiological characteristics and high-yield techniques with SRI rice in N. Uphoff et al., eds.,
Assessments of the System of Rice Intensification, 116-124 http://ciifad.comell.edu/sri/proc1/sri 27.pdf

Wang, S. H., W. X. Cao, D. Jiang, T.B. Dai, and Y. Zhu. 2003. Effects of SRI technique on physiological characteristics and population development in rice. Chinese Journal of Rice Science, 17: 31-36.

Yu, H. G, F. Q. Zhu, and C. L. Wang. 2003. A preliminary report of the application of the high-yielding techniques of SRI in single cropping hybrid rice. Hybrid Rice, 19: 33-35.

Yuan, L. P. 2001. The system of rice intensification. Hybrid Rice, 16: 1-3.

Yuan, L. P. 2002. A scientist's perspective on experience with SRI in China for raising the yields of super hybrid rice in: N. Uphoff et al. eds., Assessments of the System of Rice Intensification, 23-25 http://ciifad.cornell.edu/sri/procl/sri 06.pdf

Zheng, J. G., X. J. Lu, X. L. Jiang, and Y. L. Tang. 2004. The System of Rice Intensification for super-high yields of rice in Sichuan basin in T. Fischer et al. eds., New Directions for a Diverse Planet: Proc. of the $4^{\text {th }}$ Intl. Crop Science Congress http://www.cropscience.org.au/icsc2004/poster/2/3/3 19 zhengig.htm

Zhong, H. M., A. M. Huang, J. P. Liu, J. N. Li, F. B. Wu and F. P. Ouyang. 2003. Analysis on the yieldincreasing effects and economic benefits of the system of rice intensification SRI in hybrid rice. Hybrid Rice, 18: 45-46.

Zhu, D.F., S. H. Cheng, L. P. Zhang and X. Q. Lin. 2002. Tillering patterns and the contribution of tillers to grain yield with hybrid rice and wide spacing in $\mathbf{N}$. Uphoff et al. eds., Assessments of the System of Rice Intensification, 125-131 http://ciifad.comell.edu/sri/procl/sri 28.pdf

Zhu, D. F., ed. 2006. The Theory and Practice of SRI, Chinese Press for Science and Technology in Agriculture, Beijing.

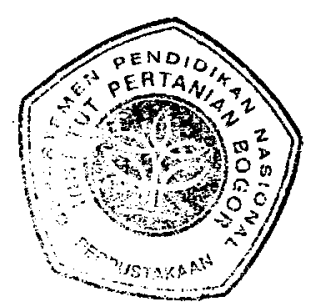

